\title{
Interdisciplinary Research in Education
}

Volume 4, Issue 1, 2019: 99-110

\section{लैड्गिक दृष्टिमा सलिजो उपन्यासको भाषा}

\author{
राजेन्द्र खनाल (पिएच. डी.) \\ उपप्राध्यापक \\ शिक्षाशास्त्र केन्द्रीय विभाग \\ त्रिभुवन विश्वविद्यालय, काठमाडौं, नेपाल \\ Email: sauravabhirk@gmail.com
}

\begin{abstract}
सारसङ्क्षेप
लैड़िगिक समालोचनाको प्रमुख पक्ष लैड़गिकताको भाषाका विविध सन्दर्भहरूको परिचय दिई 'सलिजो' उपन्यासमा प्रयुक्त भाषाको लैड़िगिक दृष्टिले विश्लेषण गर्नु यस लेखको प्रमुख उद्देश्य हो। प्रस्तुत लेखमा लैड़गिकताको भाषाका विविध स्वरूपहरूलाई उदाहरणसहित प्रस्तुत गरिएको छ। त्यस्तै, 'सलिजो' उपन्यासमा प्रयोग गरिएको भाषाको लैड़गिक दृष्टिले मूल्याङ्कन गरिएको छ। पुस्तकालयीय अध्ययन प्रक्रियाबाट सामग्री सङ्कलन गरी सलिजो उपन्यासलाई प्राथमिक स्रोत तथा विभिन्न सैद्धान्तिक ग्रन्थलाई द्वितीयक स्रोत सामग्रीका रूपमा लिइएको यस लेखमा विश्लेषणात्मक विधिको उपयोग गरिएको छ। 'सलिजो' उपन्यासबाट लैड़गिकताको भाषाका सन्दर्भसाँग सम्बन्धित तथ्याङ्कहरूको टिपोट गरी विश्लेषण गरिएको छ। यस उपन्यासमासमालिड्गी तथा तेस्रो लिड्गीहरूका आपसी सम्बन्धसूचक भाषिक प्रयोग सन्तुलित र संवेदनशील रहेको छ। उपन्यासमा रहेको भाषा लैड्रिक दृष्टिले मूल्याङ्कन गर्दा उपयुक्त छ।
\end{abstract}

विशेष शब्दावली : लैड्गिक समालोचना, लैड्गिकताको भाषा, यौनिक अल्पसड्ख्यक, वाक्प्रतीक, लैड़िकविभेद

\section{विषयप्रवेश}

लैड़्गिक अवस्था तथा स्तर चिनाउने किसिमबाट एउटा लैड़्गिकता भएको वर्ग/व्यक्तिले अर्को लैड़गिकता भएको वर्ग/व्यक्तिसँग भाषिक व्यवहार गर्दा फरक वा भिन्न किसिमले सड्केत गर्नु तथा एउटा लैड्गिक वर्गले अर्को लैड़गिक वर्गमाथि भाषिक हिसाबले विशेष सड्केत गर्नु, चिन्हित सड्केतको प्रयोग गर्नु तथा एउटा लैड्गिक अवस्थाका व्यक्तिसँग सम्बन्धित भाषालाई मानक र सर्वसामान्य रूपमा प्रयोग गर्नुका साथै खास लैड्गिकता र यौनिकता भएका व्यक्ति तथा समूहले आफ्नै किसिमका विशेष भाषिक सड्केतको प्रयोग गर्ने भाषिक व्यवहारको अवस्था नै लैड़्गिकताको भाषा हो। महिलाले पुरुषलाई गर्ने भाषिक व्यवहार, शब्द, आदर, वाक्य तथा पुरुषले महिलालाई गर्ने भाषिक व्यवहार शब्द, आदर, वाक्य र समग्र संवाद अनि बोध अभिव्यक्तिका सन्दर्भहरूको विश्लेषण यसैअन्तर्गत गरिन्छ। त्यस्तै, महिलालाई सर्वसामान्यले गर्ने सम्बोधन र भाषिक परिचय तथा पुरुषलाई सर्वसामान्यले गर्ने भाषिक व्यवहारमा रहेको लैड्गिकताको अवस्था पनि 
विश्लेषण गर्न सकिन्छ। लैड्गिकताको भाषामा महिला र पुरुषका लागि प्रयोग गरिने भाषिक संरचना, उच्चारण, शब्दभण्डारको प्रयोग महिला, पुरुष तथा अन्य लिड्गले गर्ने भाषिक सड्केतहरू, विभिन्न लैङ़गिकता र यौनिकता भएका व्यक्तिहरूलाई चिनाउन प्रयोग गरिने बिम्ब, प्रतीक तथा विशेष शब्दावली आदिको खोजी गरिन्छ। यस लेखमा लैड्गिकताका भाषासम्बन्धी सैद्धान्तिक पक्ष र उदाहरण प्रस्तुत गरिएको छ भने सलिजो उपन्यासमा प्रयोग भएका शब्द, वाक्य संवाद आदिको विश्लेषण गरिएको छ।

\section{अध्ययनको उद्देश्य}

लैड़गिक समालोचनाको प्रमुख पक्ष लैड्गिकताको भाषाका विविध सन्दर्भहरूको परिचय दिई सलिजो उपन्यासमा प्रयुक्त भाषाको लैड्गिक दृष्टिले विश्लेषण गर्नु यस लेखको प्रमुख उद्देश्य हो ।

\section{पूर्वकार्यको पुनरावलोकन}

लैड्गिकताको भाषाका सम्बन्धमा नेपालमा खासै अध्ययन भएको पाइंदैन। खनाल (२०७४) द्वारा लैड़िक समालोचना : सिद्धान्त र प्रयोग शीर्षकको ग्रन्थमा लैड्गिकताको भाषाका सम्बन्धमा सैद्धान्तिक स्वरूप तयार गरी नेपाली प्रतिनिधिमूलक उपन्यासको अध्ययन गरिएको छ। "लैड्गिकताको भाषिक पक्षका सन्दर्भमा स्वास्नीमान्छे उपन्यासको भाषा तत्कालीन समाज तथा परिवेशसँग स्वाभाविक भए तापनि लैड्गिक दृष्टिले सचेत संवेदनशील तथा सन्तुलित छैन । तीन घुम्ती उपन्यासमा भाषा पात्रानुकूल र स्वाभाविक भएरै पनि लैड्रिक दृष्टिले संवेदनशील र सन्तुलित छ। सहयात्री उपन्यासमा रहेको भाषा आकर्षक र स्वाभाविक छ तर लैड्गिकताका दृष्टिलसंवेदनशी बन्न सकेको छैन। समानान्तर आकाशउपन्यासमा प्रयुक्त भाषा स्वाभाविक, सान्दर्भिक र सन्तुलित छ। अर्धसत्य उपन्यासको भाषा सुन्दर प्रभावोत्पादक भएरै पनि लैड्गिक दृष्टिले सन्तुलित छैन" भन्ने निचोड निकालिएको छ। त्यस्तै नेपालका अधिकांश उपन्यासमा लैड्गिकताको भाषा विभेदकारी र असन्तुलित रहेको जनाइएको छ भने केही स्रष्टाहरूले सचेततापूर्वक भाषा प्रयोग गरेको जनाइएको छ। तर अन्तराष्ट्रिय सन्दर्भमा पर्याप्त अध्ययनहरू भएका छन् । केही अध्ययन निम्नानुसार छन् :

वेदरल (सन्. २००२) को जेन्डर, ल्याङ्ग्वेज एन्ड डिस्कोर्स नामक कृतिमा परिचयात्मक सन्दर्भसहित सेक्सिस्ट ल्याङ्ग्वेज, भाषिक क्षमता र बोलीमा भिन्नता, महिलाको भाषा, सड्कथनमा लैड्रिकता, भाषिक संवाद र लैड़िकता, भाषा, सड्कथनसविस्तार चर्चा गरिएको छ। भाषा र लैड़िकताका सन्दर्भमा विभिन्न अनुसन्धाताले निकालेका निष्कर्षको प्रस्ट सन्दर्भ दिएर निर्माण गरिएको यस ग्रन्थमा पुरुष तथा महिलाका जैविक विभेद/भिन्नताले फरक पार्ने भाषिक अभिव्यक्ति र उच्चारण एवम् सामाजिक सांस्कृतिक वा जातिगत पृष्ठभूमिका आधारमा देखा पर्ने लैड़िक विविधताका पक्षहरूलाई विशिष्ट र वैज्ञानिक ढड़ले उठान गरिएको छ। जैविक रूपमा पुरुषमा ल्यारेड्स वा भ्वाइसबक्स ठूलो हुने हुनाले पुरुषको स्वर ठूलो र सघन हुने तथा महिलाको भोकल कर्ड पातलो हुनाले कम्पन बढ़ी पैदा गर्दे लामो लय तथा लयात्मक र सुमधुर आवाज निस्कने कुरा (पृ. ४९) उल्लेख गरिएको छ। त्यस्तै समाज निर्मित भाषिक आचरणका कारणले महिलाको बोली वा अभिव्यक्तिमा सामाजिक मूल्यको बढी प्रभाव परेको हुन्छ भने पुरुषको भाषाले उनीहरूको सामाजिक स्तरलाई सङ्केत (पृ. प६) गरेको हुन्छ भन्ने कुरा जनाइएको छ। पुरुषको भाषा बढी तर्कपूर्ण, महत्त्वपूर्ण र अर्थपूर्ण हुने तर महिलाको भाषा भावनात्मक, अनिर्णयात्मक एवम् सौन्दर्यपक्षमा केन्द्रित (पृ.१२४) हुने कुरा जनाउँदै सामाजिक परिवेशले निर्धारण गरेका भूमिकाका आधारमा लैड़िकताको भाषा व्यवहृत हुने निष्कर्ष निकालिएको छ। 
लैड़िक दृष्टिमा 'सलिजो' उपन्यासको भाषा / 101

एकर्ट एन्ड गिनेट (सन् २००३)को ल्याड़ग्वेज एन्ड जेन्डरमा लैड़िकता र यससँग सम्बन्ध राख्ने भाषिक प्रयोगका सन्दर्भहरू उल्लेख गर्दे बालक जन्मँदादेखि नै उनमा लैड़िक विभेदगत व्यवहारहरू हुने कुरा उल्लेख गरिएको छ। नवजात शिशु अवस्थामा नै शिशु रुने कराउने तरिकाबाट नै लैड्रिकतामा फरकपन आउने धारणा रहेको उल्लेख गरिएको छ।आमाबाबुले बाल्यावस्थामा रहेका छोराछोरीलाई गर्ने व्यवहारहरूबाट नै लैड्रिक भेद निर्माण हुने बताइएको छ। जस्तै : छोरीलाई सरल र स्वीकारयोगय शब्द जहाँ माया तथा स्नेह प्रकट हुन्छ भने छोरालाई उपेक्षा र रुखो व्यवहार देखाइन्छ, जसका कारण छोराहरू चुनौती स्वीकार गर्न सक्षम बन्दै जान्छन् र छोरीहरू आश्रय खोज्न अभ्यस्त हुँदै जान्छन् भन्ने तर्क पेस गरिएको छ।

छोराहरू बाबुको व्यवहार (हक्की स्वभाव) को नक्कल गर्दछ् भने छोरीहरू आमाजस्तै घरायसी र शृड्गार कार्यमा बढी केन्द्रित रहन्छन्। यसै सन्दर्भमा बुभा (सन् १९४९) को उद्धरण 'महिला जन्मँदैनन् उनीहरूलाई बनाइन्छ, लाई समेत पुष्ट्याईँ गरिएको देखिन्छ। साथमा पुरुष पनि जन्मँदैनन् उनीहरूलाई बनाइन्छ, भन्ने अभिव्यक्ति पनि दिइएको छ। स्त्रीले गर्ने भाषिक उच्चारणमा कम स्ट्रेस, कोमलता तथा लयात्मकता रहने तर पुरुषले गर्ने उच्चारणमा बढी स्ट्रेस, कठोरता रहने कुरा अनुसन्धानबाट प्राप्त तथ्यसहित प्रस्तुत गरिएको छ ।शब्दको तहमा पुरुषलाई जनाउन प्रयोग हुने वाक्यमा रहने शब्दहरू र स्त्रीलाई जनाउन प्रयोग हुने शब्दहरू फरक फरक रहेको कुरा उल्लेख गरिएको छ। सामाजिक सक्रियता वा भूमिकामा स्त्रीहरू परोक्ष्य रहने हुनाले सामाजिक सम्प्रेषणात्मक भाषिक प्रयोग, आत्मविश्वास तथा तर्कहरूमा उनीहरू पछाडि रहेको कुरा तर्कसहित पुष्टि गरिएको छ। भाषाको स्तरीय र व्याकरणिक प्रयोगका सन्दर्भमा पुरुषभन्दा महिलाहरू बढी सचेत र सान्दर्भिक रहेको स्पष्ट पारिएको छ। जस्तै : महिलाको व्याकरण पुरुषको भन्दा स्तरीय छ। आवश्यकताअनुसार भाषिक समायोजनमा महिला अगाडि रहेका हुन्छन्। समग्र स्तरीय व्याकरणिक प्रयोगमा महिला सचेत रहन्छन् । सामाजिक स्तरअनुसार पनि पुरुषभन्दा महिलाको भाषिक प्रयोग स्वाभाविक रहेको देखिन्छ (पृ. २९३)।पचास वर्ष अगाडि सोच्न नसकिने जीवन व्यवहारहरू अहिले चल्न सम्भव भएको कुरा उल्लेख गर्दे नवीन चेतना र वैचारिक परिवर्तनका पक्षहरू प्रस्तुत गरिएको छ। जस्तै : गे म्यारिज, एकल मातृत्व त्यस्तै गृहकार्य र बच्चाको स्याहार पुरुषबाट हुनु, समलैड़िकतालाई सगर्व सार्वजनिक गर्नु, महिलाहरूले बिहे अगावै कुमारीत्व भड्न भएको सगर्व घोषणा गर्नु, महिलाहरू आर्थिक स्वतन्त्रतामा रहनु, पुरुषको नियनत्रणबाट पूर्ण मुक्त हुनु आदि (पृ. ३३१)। अमेरिकी भाषाशास्त्री दुई महिला प्राध्यापकबाट अनुसन्धानात्मक अध्ययन विश्लेषण गरी तयार पारिएको ल्याङ्ग्वेज एन्ड जेन्डर कृति नेपाली उपन्यासमा लैड़िक चेतनाको अध्ययन विश्लेषण गर्दा उपन्यासमा प्रयुक्त भाषाको अध्ययन गर्न तथा विभिन्न सैद्धान्तिक अवधारणाका साथमा आधार तयार गरी प्रतिमान समेत निर्माण गर्न उपयोगी र सान्दर्भिक बनेको छ।

जेनेट एन्ड मेयर्होफ (सन्. २००३) द्वारा द ह्यान्डबुक अफ ल्याइ्वेज एन्ड जेन्डरलाई समकालीन विश्वमा स्थापित अनुसन्धानात्मक क्षेत्र मध्येको अत्यन्त जल्दोबल्दो तथा यथेष्ट प्रभाव बोकेको अनुसन्धेय क्षेत्र 'भाषा र लैड्रिकता'का सन्दर्भमा भएका समसामयिक, आधिकारिक सर्वसम्प्रेष्य तथा वास्तविक अनुसन्धानात्मक लेख रचनाहरूको बृहत् सड्ग्रहको रूपमा प्रस्तुत ग्रन्थ तयार पारिएको छ। पुरुषत्व तथा नारीत्वका सवालमा फेमिनिन वर्कप्लेस: स्टेरोटाइप एन्ड रियालिटी शीर्षकका एउटा अन्तक्रियात्मक शैलीको टेबल (पृ. प७४) प्रस्तुत गरिएको छ : 
फेमिनिन (नारीत्व)

अप्रत्यक्ष

मृदुभाषी

सहजकर्तामूलक

समन्वयी

जनसामन्यमा कम योगदान

सहयोगी पृष्ठपोषण

व्यक्ति र प्रक्रिया केन्द्री

प्रभाव केन्द्रीयता
मास्कलिन (परुषत्व)

प्रत्यक्ष

निडर / अभिमानी

प्रतिस्पर्धी

स्वतन्त्र

जनसामान्यसँग केन्द्रित

आक्रामक प्रतिक्रिया

कार्य र प्रतिफल केन्द्री

सन्दर्भ केन्द्रीयता

माथिको टेबलबाट प्रस्ट हुन्छ, कि महिला तथा पुरुषहरूको भाषा प्रयोग, कार्यशैली तथा भूमिकामा निकै भिन्नता रहेको हुन्छ।

स्टिवार्ट,कुपर, स्टिवार्ट तथा फ्रायड्ली (सन् २००२) को कम्युनिकेसन एन्ड जेन्डर सঞ्चार र लैड़िकताका मुख्य धारणाहरूको परिचय दिइएको छ। भाषा के हो ? बालकले भाषा कसरी प्रयोग गई्छ ? भाषिक क्षमता र त्यसमा सामाजिक सांस्कृतिक प्रभाव र दवावले कस्तो भूमिका खेल्छ ? आदि विषयलाई विशिष्ट व्याख्या गरिएको छ। त्यस्तै अशाब्दिक सन्चार, इन्कोडिड तथा डिकोडिडका सन्दर्भहरू प्रस्तुत छन् । परिवार, सम्बन्ध र विवाहलगायत शिक्षा माध्यम तथा संघसंस्थाको लैड़िकता सम्बन्धी भूमिकाको विशद व्याख्या गरिएको छ। मित्रताका सन्दर्भमा भनिएको छ : केटा साथीहरू एकापसमा ठूलो समूहमा खेल्न रुचाउँछन् तर आत्मीयता कम हुन्छ। केटी साथी सीमित हुन चाहन्छन् र आत्मीय बन्छन्। किशोर अवस्था होस् वा वयस्क अवस्था स्त्री मित्रहरू व्यक्तिगत समस्या तथा आन्तरिक संवादमा तल्लीन हुन्छन् तर पुरुष मित्रहरू क्रियाकलापगत क्षेत्र र बाहिरी पक्षमा सटिक संवाद गई्छन् । टेलिफोनमा स्त्री मित्रहरू 90 मिनेटभन्दा पनि बढी समय कुराकानी गई्छन् : व्यक्तिगत समस्या, डर, शङ्का तथा आपसी सम्बन्धका बारे । पुरुष मित्रहरू जम्मा हुने क्रियाकलापमुखी बन्ने र साभा रुचिका काम गरी सामाजिकीकरणमा बढी केन्द्रित रहन्छन् (पृ. ५९-९१) भनिएको छ।

मिल्स एन्ड मुलानी (सन् २०१९) ले ल्याङ्ग्वेज, जेन्डर एन्ड फेमिनिज्म कृति तयार गरेका छन् । यस कृतिमा भाषा, लैड्रिकता र नारीवाद, नारीवादको आवश्यकता, लैड़िकताको सैद्धान्तीकरण, नारीवादी भाषिक उपागमहरू, अध्ययन विधिका उपागम, यौनिकता, यौन तथा भावी दृष्टिकोणहरूजस्ता विषय सन्दर्भलाई उठान गरिएको छ। नारीवादी दृष्टिकोण र यसका विभिन्न धारहरूको सविस्तार चर्चा गरिएको प्रस्तुत कृति अनुसन्धात्मक कृति भएकाले यसबाट प्राप्त सूचना एवम् दृष्टिकोणहरू विश्वसनीय छन् । समलिड़ी यौनिकता र त्यससँग सम्बन्धित भाषिक व्यवहारहरूको विशिष्ट विश्लेषण गरिएकोले यस पुस्तकमा यौनिकताक विविध स्वरूपहरूको सविस्तार विश्लेषण गरिएको छ। विगतमा भएका अनुसन्धात्मक कार्यहरूका निष्कर्षलाई मूल सन्दर्भ बनाएर लैड़िकता, यौनिकता तथा नारीवाद सम्बन्धी भाषिक पक्षलाई विशिष्ट व्याख्या गरिएको छ। भाषा र यौनिकताको सम्बन्धलाई यौनिक पहिचानका रूपमा स्थापित 
लैड़िक दृष्टिमा 'सलिजो' उपन्यासको भाषा / 103

गरिएको (पृ.१४३) यस कृतिमा तेस्रो लिड्रीका छुद्टै भाषिक व्यवहार हुने भए पनि पुरुषत्वकेन्द्री भाषिक व्यवस्थाले समलिड़ी वा तेस्रो लिड्डीका विशिष्ट भाषिक सम्बन्धहरूलाई उपेक्षा गर्ने गरेको जनाइएको छ।

उपर्युक्त अध्ययनबाट प्रस्ट हुन्छ कि नेपालीमा यस सम्बन्धमा पर्याप्त अध्ययन हुन नसके तापनि अन्तराष्ट्रिय क्षेत्रमा धैरै अध्ययन भएका छन्। समकालीन समयमा लैड्गिकताका मुद्दा सबल बनेको अवस्था र समानता एवम् सशक्तीकरणको आवश्यकता प्रबल रहेकाले कृतिमा लैड्गिक सन्तुलनयुक्त भाषा प्रयोग हुनुपर्ने देखिन्छ। सलिजो उपन्यासमा के कस्तो भाषा प्रयोग गरिएको छ भन्नेबारेमा यो लेख केन्द्रित गरिएको छ।

\section{अध्ययन विधि र प्रक्रिया}

प्रस्तुत लेख वर्णनात्मक विधिमा आधारित छ। साङ्खिकीको प्रयोगविना विश्लेषण तथा मूल्याङ्कन गरिएकोयो लेख गुणात्मक प्रकृतिको अनुसन्धानहो। पुस्तकालयीय अध्ययन प्रक्रियाबाट सामग्री सङ्कलन गरी सलिजो उपन्यासलाई प्राथमिक स्रोत तथा सम्बन्धित सैद्धान्तिक ग्रन्थलाई द्वितीयक स्रोत सामग्रीका रूपमा उपयोग गरी प्रस्तुत लेखतयार गरिएको छ। विभिन्न सैद्धान्तिक ग्रन्थहरूको अध्ययन गरी लैड्रिकताको भाषाका सन्दर्भ उल्लेख भएका विविध उदाहरणसमेत प्रस्तुत गरिएको छ। उक्त उदाहरण तथा सान्दर्भिक पक्षहरूलाई आधार बनाई सलिजो उपन्यासमा प्रयोग गरिएको भाषाको तथ्यपरक विश्लेषण तथा मूल्याङ्कन गरिएको छ।

\section{लैड्गिकताको भाषा}

सामाजिक परिवेश, सांस्कृतिक अवस्था तथा सामयिक सन्दर्भहरूबाट निर्धारित महिला र पुरुषको पहिचानलाई लैड़्गिकता भनिन्छ। लैड़गिकताको क्षेत्रभित्र महिला र पुरुषको परिचय तथा भूमिका मात्र पर्दैन । यसका साथै यौनिक सन्दर्भ र यौनिकताका आधारमा निर्मित पहिचान तथा व्यवहारहरू पनि लैड्गिकताका क्षेत्रअन्तर्गत पर्दछन् । जस्तो : पृथक् लिड्गी, समलिड्गी, द्विलिड्गी, परिवर्तित लिड्गी, अन्तर्लिड्गी आदि। भाषा अभिव्यक्तिको माध्यम हो जहाँ प्रत्येक व्यक्ति आफ्ना विचारहरू आदानप्रदान गर्दछन्। अक भाषा नै परिचय तथा पहिचानको सङ्केत जनाउने वाक्रतीक पनि हो । त्यसैले लैड्गिकता र भाषाबिच सम्बन्ध हुनुपछ। लैड्गिकता प्रकट गर्ने माध्यम पनि भाषा नै हो। भाषा बिनाको लैड़्गिक पहिचान निर्माण हुन सक्दैन। यौनिक अल्पसड्ख्यकलाई चिन्ने र चिनाउने कार्यका लागि होस् वा उनीहरूको आपसी सङ्केतको स्थिति निर्माण गर्नका लागि पनि भाषा नै चाहिन्छ। सामाजिक सांस्कृतिक व्यवहारहरू र मानवीय सम्बन्धको विकास तथा सन्चरणका लागि पनि भाषा नै चाहिन्छ। महिला तथा पुरुषले गर्ने भाषिक प्रयोग, विपरीत लिड्गीतथा समलिड्गीले गर्ने भाषिक प्रयोग, तिनीहरूको परस्पर र भिन्न भिन्न परिचय तथा पहिचानका लागि प्रयोग गरिने भाषालाई लैड्गिकताको भाषा भनिन्छ।

परम्परित भाषिक प्रयोगका विकल्पमा लैड्गिक संवेदनशीलता कायम हुन सक्ने भाषाको प्रयोगमा जोड दिएर लैड्गिता र भाषालाई सन्तुलन कायम गर्नुपर्ने देखिन्छ। स्टेवार्ट एन्ड अदर्स (२००३) ले भाषाको लैड्गिक सन्तुलनका लागि निम्नानुसार विकल्पहरू प्रस्तुत गरेका छन् : 


\begin{tabular}{|l|l|}
\hline \multicolumn{1}{|c|}{ परम्परित शब्द /शब्दावली } & \multicolumn{1}{c|}{ सम्भाव्य विकल्पनहरू } \\
\hline cave men & cave dwellers, prehistoric people \\
coed & student \\
freshman & first - year student \\
Dear Sir/Madam & Dear Director of Admissions or etc. \\
mailman & mail carrier, postal worker \\
mankind & humanity etc. \\
manpower & personnel, staff \\
newsman & reporter, journalist \\
right hand man / girl Friday & assistant, aide, helper \\
weatherman & meteorologist, weather forecaster \\
men or women could have made & people could have made \\
his family & their children \\
his truck & their truck \\
\hline
\end{tabular}

(पृ. पू

माथिका उदाहरणहरूबाट प्रस्ट हुन्छ कि लैड़्गिक विभेद देखिने किसिमका भाषिक प्रयोग गर्नुको सट्टा स्वतन्त्र वा निष्पक्ष भाषिक प्रयोग गर्नु पर्दछ। नेपालीमा 'श्रीमान्', 'पत्नी' नभनी श्री मात्र भन्ने, औपचारिक वा कानुनी भाषामा महिला र पुरुषलाई समान महत्त्व दिने, 'मान्छे'का सट्टामा 'व्यक्ति' भन्ने, 'जनशक्ति' नभनेर 'मानवीय स्रोत' भन्ने, 'सभापति'का सट्टामा ‘सभाध्यक्ष', विवाहित महिला र पुरुष दुवैले एकअर्कालाई सम्मानित सम्बोधन गर्ने, महिलालाई चिनाउने शृड्गारिक र यौनिक प्रतीकको प्रयोग नगर्ने, सार्वजनिक स्थानमा यौनमूलक भाषिक व्यवहार प्रदर्शन नगर्ने आदि लैड्गिक सन्तुलनयुक्त भाषाको प्रयोग गर्नु आवश्यक देखिन्छ,

भाषिक उच्चारण (ध्वनि) मा महिला र पुरुषको भिन्नता स्वाभाविक वा प्राकृतिक हुने गर्दछ। ध्वनिको उच्चारण गर्दा गति, लय, अनुतान, बलाघात आदि महिला र पुरुषमा भिन्न किसिमका हुने अनुसन्धानबाट देखिएको छ। जैविक रूपमा पनि उच्चारण अवयवको प्रकृतिमा केही भिन्नता हुने कुरा पनि बताइएको छ। यद्यपि सामाजिक शक्ति संरचनाले भाषिक उच्चारण व्यवस्थामा कुनै पनि प्रभाव पार्देन भन्न सकिंदैन । यौवनावस्थामा पुगदा उच्चारण अवयवको परिवर्तन तथा अवस्थाका कारणले केटीको भन्दा केटाको आवाज बाल्यावस्थाको भन्दा निकै भिन्न हुन्छ। यसकारण उच्चारण प्रक्रियामा प्राकृतिक भिन्नता हुन्छ, भन्न सकिन्छ। महिला र पुरुषको भाषिक ध्वानि (आवाज) मा हुने भिन्नतालाई ऋोलोके एन्ड सोरेन्सन (२००६) ले यसरी प्रस्तुत गरेका छन् : 
लेड़िक दृष्टिमा 'सलिजो' उपन्यासको भाषा / 105

\begin{tabular}{|l|l|l|}
\hline & Women & Men \\
\hline Pitch & high & low \\
Timbre & light & dark \\
Resonance & easy & forceful \\
Breath & weak & strong \\
\hline
\end{tabular}

(पृ. ९०)

माथिको तालिकाअनुसार भाषिक ध्वनिको उच्चारणमा उच्चारण अवयवको कम्पनको गति महिलामा बढी हुने गर्दछ। महिलाको ध्वानि सरल र फिका खालको हुन्छ भने श्वसन वा श्वासको बल कमजोर हुने गर्दछ, । त्यस्तै अर्कोतर्फ पुरुषमा सुर को गति कम, ध्वनि गाढा र बलपूर्वक हुन्छ भने श्वासको बल कडा हुने गर्दछ। त्यसैले महिला र पुरुषको भाषिक उच्चारणमा भिन्नता रहेको पाइन्छ। भाषिक उच्चारणमा ध्वनि कम्पनको सुरको गति पुरुषमा भन्दा महिलामा लामो र बारम्बार हुने गर्दछ (एकर्ट एन्ड गिनेट, २००३ : ६३)। त्यसैले ध्वनिमा हुने लघुता पनि महिलाले उच्चारण गर्दा दीर्घजस्तो सुनिन्छ भन्ने धारणा उनीहरूको रहेको छ। अरबी भाषाको व्याकरणमा एकवचन, बहुवचन लगायतका कोटि जनाउन महिला र पुरुषलाई भिन्न भिन्न भाषिक व्यवस्था रहेको कुरालाई एकर्ट एन्ड गिनेट (२००३) यसरी प्रस्तुत गर्दछन् :

\begin{tabular}{|l|l|}
\hline Katabta = you (masc-sg.) have written & Katabti = you (fem.sg.) have written \\
Katabtum = you (masc.pl.) have written & Katabtunna = you (fem.pl.) have written \\
Kataba $=$ he has written & Katabat = she has written \\
Kataba $:=$ they two (masc.) have written & Katabata $:=$ they two (fem.) have written \\
Katabu: = they (masc-pl.) have written & Katabna = they (fem.pl.) have written \\
\hline
\end{tabular}

(पृ. ६४)

उपर्युक्त उदाहरणमा पुरुषत्व र नारीत्व जनाउन प्रयोग गरिने वाक्यहरू भिन्न भिन्न रहेका छन् । पुरुषसँग सम्बन्धित एकवचन, बहुवचन जनाउन प्रयोग हुने शब्दभन्दा महिलासँग सम्बन्धित एकवचन, बहुवचन जनाउन प्रयोग हुने शब्दमा परसर्ग थपिएको वा बढी चिन्हित भाषाको प्रयोग गरिएको देखिन्छ । यसरी भाषामा लैड़ििक भिन्नताका संरचनाहरू विश्वव्यापी भाषामा नै पाइन्छु् कतिपय भाषामा बढी देखिन्छन् भने कतिपय भाषामा कम मात्रामा भिन्नताका सड्केतहरू पाइन्छ, ।

विश्वको लैड़गिक विकासको इतिहाससँगै लैड़गिक भाषाको सम्बन्ध पनि जोडिएको पाइन्छ । महिलालाई घरायसी र पारिवारिक काममा मात्र सिमित गरिरहँदा उनीहरूको सामाजिक अन्तर्क्रिया नहुने र औपचारिक भाषिक प्रयोग गर्नु नपर्ने स्थिति हुँदासम्म महिलाहरूमा भाषा प्रयोगमा सङ्कुचन रहेको पाइन्छ। विभिन्न कान्ति र आद्योगिकीकरण पछि, महिलाहरू सामाजिक, पेसागत तथा व्यावसायिक भूमिकामा सक्रिय हुँदै गएपछि महिलाहरूले भाषाको प्रयोगमा मानक रूपको प्रयोग गर्न थालेको देखिन्छ । 
विद्यालयमा शिक्षकका रूपमा क्रियाशील हुँदा महिलाहरूले मानक व्याकरणको प्रयोगमा अभ सक्षमता हासिल गरेको देखिन्छ । अहिलेको विश्वव्यापीकरणको युगसम्म आइपुगदा महिला र पुरुषको भाषिक प्रयोगको क्षमता समानान्तर किसिमले विकास भइरहेको देखिन्छ। अभ महिलाहरू बढी शुद्ध र स्पष्ट व्याकरणिक प्रयोगसहित भाषा प्रयोगमा सक्षम रहेको समेत पाइन्छ। तसर्थ पितृसत्तात्मक समाजले भन्ने गरेको महिलाहरू स्तरीय र मानक भाषा प्रयोगमा अक्षम हुन्छन् भन्ने मान्यता पूर्णतः विस्थापित भएको देखिन्छ। भाषा र लैड़गिकतामा मुख्यतया जैविक रूपमा हुने भाषिक प्रयोगको भिन्नता, सामाजिक, रूपमा स्थापित मान्यताका आधारमा पितृसत्ताको आँखाबाट महिलालाई गरिने भाषिक व्यवहार र बनाइएका भाषिक प्रतीकको सम्बन्ध तथा महिलाहरूमा विकसित भइरहेको भाषिक सक्षमताको स्थितिले निर्माण भएको महिला र पुरुषको भाषिक अवस्थाको सन्दर्भगत क्षेत्र पर्दछ। यसै सन्दर्भमा भाषा र यौनिकताका पक्षहरू समेत विश्लेष्य क्षेत्र मानिन्छन् । पृथक् लिड्गले अर्को लिड्गीव्यक्तिलाई प्रयोग गर्ने यौनिक भाषा, यौनिक अल्पसड्ख्यकलाई पृथक् लिड्गी व्यक्तिले गर्ने भाषिक व्यवहार तथा समलिड्गी व्यक्तिहरूले एकापसमा गर्ने भाषिक सङ्केत र व्यवहारका सन्दर्भ पनि भाषा र लैड़गिकताअन्तर्गत नै पर्दछ् ।

यौनिकताको नयाँ पहिचान र व्याख्या तथा वैधता प्राप्त भए पछि सोहीअनुसार विशेष प्राविधिक शब्दावलीको पनि निर्माण र प्रयोग हुँदै गइरहेको देखिन्छ। हुन त यौनिकताको भाषाअन्तर्गत परम्परागत रूपमा स्थापित विपरीत लिड्ग्गीयौनिकता र सोअनुसारका भाषिक प्रयोग पनि नपर्ने होइन तर मूलतः समलिड्गी यौनिकतासँग सम्बन्धित उनीहरूलाई पृथक् लिड्गहरूले प्रयोग गर्ने भाषा र उनीहरूको आपसी सम्पर्क भाषालाई जोड दिइन्छ।

पुरुष समलिड्गी यौनिकता भएका व्यक्तिहरूले आफ्नै समूहको खास भाषा (कोड ल्याङ्ग्वेज) प्रयोग गर्ने गरेको भए तापनि महिला समलिड्गी यौनिकता भएका व्यक्तिहरूले त्यस्ता विशेष शब्दावली प्रयोग नगर्ने बरु नारीवादी शब्द र सामान्य भाषाको प्रयोग गर्ने गरेको पाइन्छ (जनेट एन्ड मेयर्होफ, २००३ : १२१)। विभिन्न यौनिक गुण भएका व्यक्तिहरूले विशेष किसिमका भाषिक सङ्केत र व्यवहारहरू प्रकट गर्ने गर्दछन् । पृथक् लिड्गीहरूले पनि भिन्न र विशिष्ट भाषिक व्यवहारहरू प्रस्तुत गर्दछन् तर यस्ता यौनिक सङ्केतहरू यौन चाहनाको पूर्ति वा सन्तुष्टिमा केन्द्रित रहेका हुन्छन्। पृथक् लिड्गी व्यक्तिहरूले निर्धारण गरेका मानक भाषिक प्रयोगभन्दा भिन्न र विशिष्ट किसिमका भाषिक व्यवहार समलिड्गी पुरुष तथा महिलाहरूले गर्ने गरेको पाइन्छ (मिल्स एन्ड मुलानी, २०११: १२४)। बेलायतमा प्रयोगमा भएको विशेष भाषा (Polari) लाई विश्वका अन्य गे तथा लेज्वियनले समेत स्वीकार गरेको पाइएको छ। Polari अर्थात् समलिड्गी यौनिकता भएका व्यक्तिले प्रयोग गरेको भाषाको उदाहरण मिल्स एन्ड मुलानी (२०११) ले यसरी प्रस्तुत गरेका छन् :

'We would zhoosh our riahs, powder our eeks, climb in to our bona new drag, don aourir batts and troll off to some bona bijou bar.'(पॄ. १२५) 
उपर्युक्त उदाहरण प्रयोग गरिएका विशेष शब्दको अर्थ यस प्रकार प्रस्तुत गर्न सकिन्छ :

\begin{tabular}{|l|l|}
\hline \multicolumn{1}{|c|}{ शब्द } & \multicolumn{1}{|c|}{ अर्थ } \\
\hline Zhoosh & fix \\
riahs & hair \\
eeks & face \\
bona & nice \\
drag & clothes \\
batts & shoes \\
troll off & cruise \\
bijou & small \\
\hline
\end{tabular}

त्यस्तै, हङकडमा पनि पुरुष समलिड्गीको भाषालाई Mem-ba भनिन्छ। जब पृथक् लिड्गीयौनिकता भएका व्यक्ति तथा सार्वजनिक मान्यताभन्दा भिन्न रहेर विशेष बोध अभिव्यक्तिका लागि गे मेनहरूले mem-ba को प्रयोग गर्ने गरेको पाइन्छ। mem-ba का केही उदाहरण यस प्रकार छन् : diu - yu (to go cruising), yu - tong (cruising, places), chau - fui (to be attracted to white men), wui-so (gay bars) (पृ. १२५) । त्यसैले कुनै पनि ठाउँमा रहेका समलिड्गी यौनिकता भएका व्यक्तिहरूले आ-आफ्नै विशेष शब्दावलीको प्रयोग गर्ने गरेको देखिन्छ। आफ्ना यौनिक चाहना र आवश्यकता पूर्ति गर्ने अभिप्रायले विशेष भाषिक व्यवहार प्रयोग गर्ने गर्दछन् भने पृथक् लिड्गीयौनिकता भएका व्यक्तिहरू हुन् वा समलिड्गी यौनिकता भएका व्यक्तिहरू हुन् उनीहरूले भिन्न किसिमका यौनिक भाषाको प्रयोग गर्दछ् ।

\section{सलिजो उपन्यासको भाषा}

सलिजो उपन्यास वैचारिक सघनतासहित यौनिक अल्पसड्ख्यकका स्वतन्त्रतामूलक जीवनलाई सकारात्मक स्थापनामा जोड दिएर समानता र मानवीय मूल्यको चेतना प्रस्तुत गरिएको उपन्यास हो। भाषा विचार प्रवाहको माध्यम त हुँदै हो साथै पात्रहरू वा लेखकद्वारा प्रयुक्त भाषिक सन्दर्भ तथा शब्दभण्डार, भाषिक प्रयोग र प्रस्तुति एवम् संवादमा प्रयोग हुने गरेका सम्बोधनमूलक शब्द आदिले कृतिमा प्रकट गर्न खोजेको चेतना, मनोवृत्ति तथा भावनालाई प्रतिबिम्बन गरेका हुन्छन् ।

यस उपन्यासमा उपन्यासकारले अपेक्षित, पहिचानमूलक, स्वाभाविक, सान्दर्भिक तथा संवेदनशील भाषिक प्रयोगका माध्यमबाट उपन्यासलाई सोद्देश्यमूलक एवम् सार्थक तुल्याएका छन्। पात्रहरूको मनोवृत्ति र धारणा एवम् दृष्टिकोणहरूलाई यथार्थ रूपमा उजागर गर्ने माध्यम उनीहरूले प्रयोग गरेको भाषिक व्यवहार नै हो । सलिजोमा पात्रानुकूल भाषिक सन्दर्भहरू रहेका छन् जसले उपन्यासलाई प्रभावकारी बनाएको देखिन्छ। नारी समलिड्गीहरूको भाषिक सड्केत तथा प्रयोग, समलिड्गीयौनिकतालाई समभाव राख्ने पात्रहरूको सकारात्मक एवम् संवेदनशील भाषा अनि 
विसमलिड्गीपात्रहरूको पितृसत्तात्मक अहम् र नकारात्मक विचार प्रकट गर्ने भाषिक सन्दर्भ आदि पक्षलाई उपन्यासकारले अत्यन्त संवेदनशील भएर सचेततापूर्वक प्रस्तुत गरेकाले लैड़गिक दृष्टिले मूल्याङ्कन गर्दा सलिजोमा प्रयुक्त भाषा अपेक्षित, उपयुक्त, प्रभावकारी एवम् स्वाभाविक छ तथापि कतिपय प्रसड्गमा प्रकृतवादी प्रभाव बढेकाले शब्दभण्डार एवम् प्रस्तुतिमा खुलापन अनुभव हुन्छ। फलतः यौनिक आकर्षण, सम्बन्ध तथा सन्तुष्टिको प्रकटनमा प्रयोग भए पनि समलिड्गीयौनिक सम्बन्ध भएका नारी पात्रप्रति लेखकीय दृष्टि संवेदनशील बन्न नपुगेको र तेस्रो लिड्गीप्रति पनि संवेदनशील सन्तुलित भाषिक प्रयोगमा विचार नपुय्याएको देखिन्छ। तर यो अत्यन्त नगण्य छ। अधिकांश भाषिक प्रयोगमा लेखकीय सन्तुलन पुगेको प्रस्ट छ। विचार पक्षको गम्भीरताले भाषिक पक्षमा देखिएका छिटफुट असन्तुलनलाई ढाकेको देखिन्छ, ।समग्रमा विचार र भाषा सन्तुलित र स्वाभाविक रहेको छ। त्यस्तै विभिन्न बिम्ब, प्रतीक, अलड्कार, चयन, विचलन, समानान्तरता, उखानटुक्का, नवीनता आदि पक्षका कारणले प्रस्तुति अत्यन्तै प्रभावोत्पादक बनेको छ। शैली पक्षमा देखिएको चातुर्यले सलिजोसुन्दर बनेको छ।

“आजदेखि म तिमीलाई जीवन साथी स्वीकार गईु (पृ. ४३)" - ज्वाला

“आजदेखि म पनि तिमीलाई जीवन साथी स्वीकार गई (पृ. ४३)।" - रुपा

यी दुई उदाहरणमा बेहुला बनेकी ज्वाला र बेहुली बनेकी रुपाले एकअर्कालाई 'तिमी' जस्तो मध्यम आदरसूचक सम्बोधन र समभाव तथा सहृदयता प्रकट गर्ने अभिव्यक्ति दिएका छन् भने दुवैले ' जीवन साथी' शब्द प्रयोग गरेका छन्। यसले सहभाव तथा समानान्तर तहलाई सङ्केत गर्दछ। 'लेज्बा' तथा 'लेज्बी' कमश: ज्वाला र रुपाका गोप्य नाम (पृ. ४४)। उपन्यासकारले नवीन शब्द निर्माण गर्दे प्रस्ट तथा साङ्केतिक नामकरण गरेका छन् । यसले भाषा प्रयोगमा देखिएको चातुर्य र संवेदनशीलतालाई उजागर गर्दछ। 'लेज्वा' अर्थात् पुरुषत्वका गुण एवम् भूमिका निर्वाह गर्ने युवती वा ज्वाला तथा 'लेज्बी' अर्थात् स्त्रीत्वका गुण एवम् भूमिका निर्वाह गर्ने युवती वा रुपा प्रस्ट पहिचानसहित ‘लेज्बियन' शब्दलाई उपन्यासकारले मौलिकता प्रदान गरेका छन् । गे१ र गे२ ले ज्वाला र रुपासँग संवाद गर्दा प्रयोग गरेका शब्द (पृ. ४९-५१) अड्ग्रेजी शब्दका छोटकरी रूप हुन्। आपसी सड्केतका लागि बनाइएका यस्ता शब्दले पनि यौनिक अल्पसड्ख्यकका भाषिक कोडलाई जनाएका छन् । जस्तै : 'प्रोब्', 'पेट्रो', 'प्रेजन्', 'टेम्प', 'सिभ् युनि', 'हनिम्' ‘लेज्', ' थ्रिजी' 3G, 'मेम्', 'रिभोल्', 'सेलिब्' आदि । यी शब्द पुरुषसमलिड्गीहरूले प्रयोग गरेका भाषाका उदाहरण हुन् । यसबाट विशेष समुदायले आफ्नो पहिचानसहित आफ्नो समुदायका सदस्यहरूमा मात्र सन्चारका लागि विशिष्ट भाषिक व्यवहार अपनाउँछ् भन्ने कुरालाई उजागर भएको छ।

पुरुषत्व एवम् स्त्रीत्वका सन्दर्भमा स्थापित लैड़्गिकताका भाषिक सन्दर्भलाई उपन्यासकारले प्रस्तुत गर्दै पुरुषत्वअन्तर्गत पुरुषता, कठोरता, उग्रता, वीरता, साहस, निर्भीकता पर्ने र स्त्रीत्वअन्तर्गत सङ्कोच, निर्बलता, भीरुता, सहिष्णुता, लज्जा, कोमलता (पृ. ६७) जस्ता पक्षहरू पर्ने जनाएका छन्। तेस्रो लिड्गीडाइमनको स्वरूप, स्वभाव र भाषिक प्रयोगमा उपन्यासकारले परम्परागत भाषिक पक्षलाई प्रस्तुत गरेका छन्। "नारीभन्दा नखरमाउलो र पुरुषभन्दा भलादमी खालको हाँसो फिँजाएर ताली पड्काउँदै सोध्छ, “हाइहाइ, कहाँ जाने नाइँ ?” (पृ. ७४)।” “म हिजडा हुँ नाइँ।", (पृ. ७४)। यहाँ प्रस्तुत गरिएका 
लैड़िक दृष्टिमा 'सलिजो' उपन्यासको भाषा / 109

सन्दर्भले पात्रानुकूलको भाषा र हाउभाउलाई अत्यन्त प्रभावकारी ढड्गले व्यक्त गरेका छन् तर लैड्गिक संवेदनशीलताका दृष्टिले हेर्दा 'नखरमाउलो' ‘हिजडा' जस्ता शब्द प्रयोग गर्न नहुने देखिन्छ। त्यस्तै बिहे दर्ता कार्यालयको चुर्सेले समलिड्गीज्वाला र रुपालाई गरेको हिंसाजन्य भाषिक व्यवहारले “तिमीहरूलाई मज्जा त आउँछ (पृ. ७९) ?" समलिड्गीहरूप्रति गरिने भाषिक हिंसालाई उजागर गरेको छ। ज्वाला तथा रुपाले चुर्सेलाई उपेक्षा गर्दे बैठक कोठामा बसेर गाली गरेका शब्दहरू प्रतीकात्मक र परिवेशअनुसार छन् तर उक्त शब्दले समलिड्गीहरूमा रहेको विपरीत लिड्गीहरूप्रतिको नकारात्मक सोचाइलाई उजागर गरेको देखिन्छ। यहाँ सकारात्मक मनोवृत्तितर्फको अभिमुखीकरण स्थापित हुन सकेको छैन । जस्तै : मोरो, असत्ती, बापती, पातकी, हराम, बजिया, छटेल, बेसुल्लो, फुँडो, रन्डो (पृ. ५०)। उपर्युक्त नकारात्मक शब्दको उपस्थिति अपेक्षित देखिदैन। सबै खालका लैड्गिकता र यौनिकता भएका मानवहरूमा सबैले सबैलाई समभाव राख्नुपई भन्ने लेखकीय आग्रहमा बाधा पर्ने देखिन्छ। त्यस्तै डाइमनका लागि खर्चिएका प्रशंसापरक शब्दहरू फरासिलो, मिजासिलो, मज्जाको, सुबानको, मनमोजी, भलाद्मी, मद्दती, मिलनसार, सुधो, खुलस्त (पृ. ५०) स्वाभाविक र अपेक्षित देखिन्छन् ।

समलिड्गीहरूप्रति समभाव राख्दै समलिड्गीविवाह गरेर जोडी बनेकामा रुपालाई डा.चकोरले सम्मान र बधाई दिन्छन् । "मेरो तिमीलाई धैरैधैरै बधाई छ (पृ. ९१)।" यस्तो सम्मानजनक भाषाको प्रयोगमा सबलता देखिन्छ। समलिड्गीसम्बन्धप्रति नकारात्मक दृष्टि राख्ने विसमलिड्गीसमाजका प्रतिनिधि पात्र रूपाका बाबु र आमाले रुपालाई विद्यालयमा गएर सामाजिक बेइज्जती गर्दै 'नाठा खेलाउने', 'समाजलाई नर्क बनाउने', 'स्कुले नानीलाई वेश्या बनाउने' जस्ता हिंसाजन्य भाषाको प्रयोग (पृ. १३६) गर्दे आरोप लगाएका छन्। परम्परागत पितृसत्तात्मक सड्कीर्ण र अन्धविश्वासी संस्कारको नकारात्मक दृष्टिकोणलाई उपर्युक्त उदाहरणले स्वाभाविक उजागर गरेका छन्। परम्परित समाजले समलिड्गीलाई गर्ने व्यवहारको सड्केत उपर्युक्त भाषाबाट स्पष्ट पार्न उपन्यासकार सक्षम देखिन्छन् । यसले समलिड्गीहरूले भोग्नुपर्ने अत्याचारलाई व्यक्त गरेको छ। त्यस्तै गरी माथिजस्तै हिंसाजन्य भाषाको प्रयोग गरी सामाजिक तहबाट रुपालाई अपमान गर्ने भाषिक व्यवहार विद्यालयको गेटको ढोकामा टाँसिएका पोस्टरमा छापिएका छन् । दुश्चरित्र, अनैतिक, पतित, कुमार्गी, आचारहीन (पृ. १६०) आदि शब्दहरू प्रयोग हुनु हिंसात्मक व्यवहार तथा अत्याचार हुन् । यसले पनि पितृसत्तात्मक सड्कीर्णता र अन्यायलाई उजागर गर्दछ। रेसमले ज्वालालाई बोलेका शब्द (पृ. १९६) "ए राँड, खुरुक्क आफ्ना सबै लुगा फुकाल् र चुपचाप भुईँमा सुत् (पृ. १९६)।" यो भाषिक हिंसाको नमुना हो। त्यस्तै रविले रुपालाई 'हिंड् खुरुक्क' भन्दै (पृ. २४४) लैड्गिक दृष्टिलेहिंसाजन्य भाषाको प्रयोग गरेको छ।

\section{निष्कर्ष}

उपन्यासकार सलिजो मा समलिड्गीतथा तेस्रो लिड्गीहरूका आपसी सम्बन्वसूचक भाषिक प्रयोग, लेखकीय विस्तार, समभाव राख्ने पात्रहरूको भाषिक व्यवहार आदिको चयन र प्रयोगमा सचेततापूर्वक संवेदनशील रहेको देखिन्छ भने विभेदकारी पितृसत्ता र विसमलिड्ग्गीहरूले समलिड्ग्गीहरूप्रति गर्ने उपेक्षापूर्ण र हिंसाजन्य भाषिक व्यवहारलाई पनि पात्रानुकूल स्वाभाविक र सान्दर्भिक ढड्गले उठान गरिएको छ। तसर्थ लैड्गिक दृष्टिले मूल्याड्कन गर्दा उपन्यासमा प्रयुक्त लैड्गिकताको भाषा सकारात्मक, सचेत एवम् संवेदनशील रहेको निष्कर्ष निकाल्न सकिन्छ। 


\section{सन्दर्भसूची}

अब्राम्स, एम.एच.एन्ड जी.जी. हार्फम. (सन् २००४).अ ग्लोसरी अफ लिटेररी टर्म्स. आठौँ संस्क. थम्सन वर्ड्स वर्थ ।

उप्रेती, सज्जीव. (२०६९). सिद्धान्तका कुरा. चौथो संस्क. काठमाडौं : अक्षर क्रियसन्स ।

एकर्ट, पी.एन्ड एस.एम. गिनेट.(सन् २००३). ल्याड्गवेज एन्ड जेन्डर. न्यूयोर्क : क्यास्त्रिज

ऋोलोके, चार्लोटी एन्ड अने स्कट सोरेन्सन. (सन् २००६). जेन्डर कम्युनिकेसन थ्योरिज एन्ड अनलाइसिस्. क्यालिफोर्निया : सेज पब्लिकेसन्स ।

खनाल, राजेन्द्र.(२०७४). लैड़गिक समालोचना सिद्धान्त र प्रयोग. काठमाडौं : सनलाइट पब्लिकेसन ।

गोडार्ड, एड़्गेला एन्ड एल.एम.पटर्स. (सन् २०००). ल्याड्ग्वेज एन्ड जेन्डर. अमेरिक: रट्लेज ।

जनेट, होल्मस् एन्ड मिरियन, मेयर्होफ. सम्पा. (सन् २००३). द ह्यान्डबुक अफ ल्याङ्वेज एन्ड जेन्डर. अमेरिका : ब्लाकवेल पब्लिसिड।

टाइसन, लुइस. सम्पा. (सन् २००६). क्रिटिकल थ्योरी टुडे. दो.सं. न्युयोर्क : रट्लेज ।

पिल्चर, जे. एन्ड आइ. ह्वेलहेन. सन् २००४. फिफ्टी की कन्सेप्टस् इन जेन्डर स्टडिज. लन्डन : सेज पब्लिकेसन्स ।

फुको, मिचेल. (सन् १९७६). द हिस्ट्री अफ सेक्सुआलिटी (भोलुम.१), न्यूयोर्क : पान्थेन बुक्स ।

बट्लर, जुडिथ. (सन् 9९९०). जेन्डर ट्रबल. न्युयोर्क : रट्लेज ।

बन्धु, चूडामणि. (२०६४). अनुसन्धान तथा प्रतिवेदन लेखन. काठमाडौं : रत्न पुस्तक भण्डार ।

बराल, कृष्णहरि र एटम, नेत्र. (२०६६). उपन्यास सिद्धान्त र नेपाली उपन्यास. ललितपुर : साका प्रकाशन ।

बुभा, सिमोन द. (सन् १९४९). द सेकेन्ड सेक्स (अनु. रमेश सुनुवार). काठमाडौँ : प्रगति पुस्तक सदन । मिलेट, काट. (सन् २०००). सेक्सुअल पोलिटिक्स (रिप्रिन्टेड). अमेरिका: युनिभर्सिटी अफ इलिनोइस प्रेस । मिल्स, सारा एन्ड मुलानी लुइस. (सन् २०११). ल्याङ्वेज, जेन्डर एन्ड फेमिनिज्म. न्युयोर्क : रट्लेज । वेदरल, आन. (सन् २००९). जेन्डर ल्याङ्ग्वेज एन्ड डिस्कोर्स (डिजिटल प्रिन्ट).न्युयोर्क: रट्लेज ।

शर्मा, मोहनराज. (२०६६). सलिजो. काठमाडौं : सीमान्त प्रकाशन ।

स्टिवार्ट,एल. पि.;कुपर, पि. जे.; स्टिवार्ट, ए. डि.; तथा फ्रायड्ली,एस. ए. (सन् २००२). कम्युनिकेसन एन्ड जेन्डर. अमेरिका : पियर्सन । 